\title{
The efficacy and safety of plasma exchange in patients with sepsis and septic shock: a systematic review and meta-analysis
}

Emily Rimmer ${ }^{1,2}$, Brett L Houston ${ }^{3}$, Anand Kumar ${ }^{1}$, Ahmed M Abou-Setta ${ }^{4}$, Carol Friesen ${ }^{5}$, John C Marshall ${ }^{6}$, Gail Rock ${ }^{7}$, Alexis F Turgeon ${ }^{8}$, Deborah J Cook ${ }^{9,10}$, Donald S Houston ${ }^{1,2}$ and Ryan Zarychanski ${ }^{1,2,4^{*}}$

\begin{abstract}
Introduction: Sepsis and septic shock are leading causes of intensive care unit (ICU) mortality. They are characterized by excessive inflammation, upregulation of procoagulant proteins and depletion of natural anticoagulants. Plasma exchange has the potential to improve survival in sepsis by removing inflammatory cytokines and restoring deficient plasma proteins. The objective of this study is to evaluate the efficacy and safety of plasma exchange in patients with sepsis.
\end{abstract}

Methods: We searched MEDLINE, EMBASE, CENTRAL, Scopus, reference lists of relevant articles, and grey literature for relevant citations. We included randomized controlled trials comparing plasma exchange or plasma filtration with usual care in critically ill patients with sepsis or septic shock. Two reviewers independently identified trials, extracted trial-level data and performed risk of bias assessments using the Cochrane Risk of Bias tool. The primary outcome was all-cause mortality reported at longest follow-up. Meta-analysis was performed using a random-effects model.

Results: Of 1,957 records identified, we included four unique trials enrolling a total of 194 patients (one enrolling adults only, two enrolling children only, one enrolling adults and children). The mean age of adult patients ranged from 38 to 53 years $(n=128)$ and the mean age of children ranged from 0.9 to 18 years $(n=66)$. All trials were at unclear to high risk of bias. The use of plasma exchange was not associated with a significant reduction in all-cause mortality (risk ratio (RR) $0.83,95 \%$ confidence interval (CI) 0.45 to $1.52, I^{2} 60 \%$ ). In adults, plasma exchange was associated with reduced mortality (RR $0.63,95 \% \mathrm{Cl} 0.42$ to $0.96 ; I^{2}$ 0\%), but was not in children (RR $0.96,95 \% \mathrm{Cl} 0.28$ to $\left.3.38 ; I^{2} 60 \%\right)$. None of the trials reported ICU or hospital lengths of stay. Only one trial reported adverse events associated with plasma exchange including six episodes of hypotension and one allergic reaction to fresh frozen plasma.

Conclusions: Insufficient evidence exists to recommend plasma exchange as an adjunctive therapy for patients with sepsis or septic shock. Rigorous randomized controlled trials evaluating clinically relevant patient-centered outcomes are required to evaluate the impact of plasma exchange in this condition.

\footnotetext{
* Correspondence: rzarychanski@cancercare.mb.ca

${ }^{1}$ Department of Internal Medicine, University of Manitoba, GC425-820

Sherbrook Street, HSC, Winnipeg R3A 1R9, Canada

${ }^{2}$ Department of Haematology and Medical Oncology, CancerCare Manitoba,

675 McDermot Ave, Winnipeg R3E 0V9, Canada

Full list of author information is available at the end of the article
}

\section{Biomed Central}

(c) 2014 Rimmer et al.; licensee BioMed Central. This is an Open Access article distributed under the terms of the Creative Commons Attribution License (http://creativecommons.org/licenses/by/4.0), which permits unrestricted use, distribution, and reproduction in any medium, provided the original work is properly credited. The Creative Commons Public Domain Dedication waiver (http://creativecommons.org/publicdomain/zero/1.0/) applies to the data made available in this article, unless otherwise stated. 


\section{Introduction}

Severe sepsis and septic shock are among the leading causes of death in patients admitted to an ICU worldwide and, despite advances in treatment and supportive care, the mortality remains greater than $20 \%$ [1-4].

Plasma exchange or plasma filtration involves the separation of plasma from whole blood, removal of the plasma, and replacement with normal saline, albumin, or fresh frozen plasma $[5,6]$. Plasma exchange has the potential to improve survival in sepsis by restoring homeostasis through the removal of harmful substances (for example, bacterial toxins, activated complement and coagulation factors and inflammatory cytokines) and, when the replacement fluid is plasma, replacement of deficient blood components (for example, coagulation factors and natural anticoagulants) [7]. Plasma exchange, however, also has the potential to cause harm by diluting or attenuating the host's adaptive response to infection.

Case reports and small observational studies in humans with septicemia or meningococcemia suggest a survival benefit of plasma or whole blood exchange when compared with expected survival rates [8-16]. While some studies have reported a fourfold increase in survival compared with historical controls [16], others have found relative survival benefits of 4 to $25 \%[13,15]$. The small sample size of these studies and the lack of a contemporaneous comparator limit our ability to draw conclusions regarding the risks and benefits of plasma exchange in sepsis and septic shock. Currently, the American Society for Apheresis lists plasma exchange as an experimental treatment for sepsis and multiorgan failure, and considerable practice variability exists in the application of apheresis technologies for the treatment of sepsis [6]. The objective of this systematic review was to examine the efficacy and safety of plasma exchange compared with usual care in patients with sepsis or septic shock.

\section{Methods}

Using an a priori published protocol (CRD 42013004290), we conducted our systematic review in accordance with the Methodological Expectations of Cochrane Intervention Reviews guidelines [17] and reported our results as per the Preferred Reporting Items for Systematic Reviews and Meta-analysis guidelines for systematic review and meta-analysis [18]. A review team comprised of experts from multiple fields (hematology, critical care, research methodology and library sciences) formulated the research question, reviewed the search strategy and review methods, and provided input throughout the review process.

\section{Research question}

Our primary research question was: 'In critically ill patients with sepsis, severe sepsis, septic shock, or disseminated intravascular coagulation due to infection, is plasma exchange, compared with usual care, associated with differences in mortality, ICU and hospital length of stay, and central venous catheter-related complications?' (Additional file 1). We included trials that met the following criteria: prospective randomized trials of human subjects; trials enrolling adults or children; at least $80 \%$ of patients diagnosed with sepsis, severe sepsis, septic shock or disseminated intravascular coagulation due to infection; and plasma exchange or plasma filtration (regardless of timing, number of treatments, replacement fluid or frequency of administration) was compared with placebo or usual care. Conventional dialysis or hemofiltration were not considered as plasma exchange, because the modalities differ in terms of plasma protein removal and replacement fluid. Our primary outcome was all-cause mortality reported at longest follow-up. Secondary outcomes included ICU and hospital lengths of stay, and safety outcomes included central venous catheter-related complications (infection, thrombosis) or procedural related complications. Additional file 2 presents inclusion and exclusion criteria.

\section{Search strategy and study selection}

We searched the following electronic databases from inception to 28 April 2014: MEDLINE (PubMed), EMBASE (Ovid), and CENTRAL (the Cochrane Library - Wiley). The Cochrane Highly Sensitive Search Strategy was used as a model for searching [19]. The original search strategy was designed for MEDLINE with input from an information specialist and then translated for other databases. The following search terms were used: 'sepsis; shock, septic; disseminated intravascular coagulation; thrombocytopenia; plasma exchange; plasma filtration; and blood component removal' (Additional file 3). We performed forward searches of included trials and relevant reviews in Scopus to identify additional citations. To identify ongoing or planned trials, we searched the World Health Organization's International Clinical Trials Registry Platform. In addition to electronic database searching, we searched abstracts and conference proceedings for the following societies from 2008 to 2012: American Society of Hematology, European Hematology Association, American Thoracic Society, International Symposium on Intensive Care and Emergency Medicine, Society of Critical Care Medicine, European Society of Intensive Care Medicine, and American Society for Apheresis. Finally, we hand-searched the bibliographies of relevant reviews and included trials for additional citations. Reference management was performed in EndNote ${ }^{\text {Tw }}$ (version X6; Thomson Reuters, Philadelphia, PA, USA). Two reviewers (ER and BLH) independently reviewed the title and abstract of each citation to determine whether a study generally met the inclusion criteria. The full text of all citations listed as 'include' or 'unsure' by either reviewer 
at this stage of screening were retrieved for full-text review. The full-text versions of potentially relevant citations were then independently assessed to determine whether the trial satisfied the inclusion and exclusion criteria. Discrepancies between reviewers were resolved through consensus in discussion with a third reviewer (RZ).

\section{Data extraction and management}

Two reviewers (ER and BLH) independently extracted data from included trials using standardized and piloted data extraction forms. Discrepancies between reviewers were resolved through consensus in discussion with a third reviewer (RZ). We extracted data including trial demographics (author, year of publication, country, funding source, publication status, duration of follow-up, number of centers involved, inclusion and exclusion criteria, and methodological quality using the Cochrane Collaboration Risk of Bias tool) [20,21]. In addition, we extracted patient demographics (age, sex, ICU admission diagnosis), Acute Physiology and Chronic Health Evaluation II score [22] or other illness severity score, number of patients requiring mechanical ventilation or vasopressors at baseline, co-interventions in the ICU (antibiotic use, vasopressors, ventilator, corticosteroids, renal replacement therapy), details of the intervention (type of apheresis procedure, number of treatments administered, volume exchanged, replacement fluid used) and details pertaining to the primary, secondary, and safety outcomes. Data management was performed using Microsoft Excel 2011 (Microsoft Excel for Mac 2011. Microsoft Corp. Redmond, WA, USA).

\section{Quality assessment}

We used the Cochrane Collaboration Risk of Bias tool to assess the internal validity of included trials $[20,21]$. This tool consists of six domains (sequence generation, allocation concealment, blinding, incomplete outcome data, selective outcome reporting, and other sources of bias) and a categorization of the overall risk of bias. Each separate domain is rated low risk, unclear risk, or high risk. If one or more individual domains were assessed as having a high risk of bias, the overall score was rated as having a high risk of bias. The overall risk of bias was considered low only if all components were rated as having a low risk of bias.

\section{Data analysis}

We analyzed data from the included trials using Cochrane Review Manager (RevMan version 5.1, 2011; The Cochrane Collaboration, Copenhagen, Denmark). For dichotomous data, we expressed summary measures of effect as risk ratios (RRs) with 95\% confidence intervals (CIs) using the Mantel-Haenszel method. We used a random-effects model for all analyses. A RR of less than 1 suggests a lower rate of death among patients treated with plasma exchange than those in the control group. We assessed statistical heterogeneity of the data using the $I^{2}$ statistic. We investigated potential sources of heterogeneity using subgroup analyses based on methodological characteristics, quality and patient characteristics. Due to the small number of included trials, systematic evaluation of publication bias was not possible.

\section{Subgroup analyses}

To investigate potential statistical heterogeneity, we performed subgroup analyses in several prespecified groups, including children versus adults and trials conducted in North America versus in other continents.

\section{Results}

Of the 1,957 records identified from electronic and hand searches, we included four unique randomized trials enrolling a total of 194 patients (Figure 1, Table 1) [23-26]. All were published in peer-reviewed, English-language journals. All trials were at unclear to high risk of bias (Table 2). One trial was conducted in North America [25], while the other three were conducted in Europe [24], Australia [23] or both [26]. Two were multicenter trials [23,26]. One trial enrolled adults only [24], one trial enrolled both adults and children [23] and two trials enrolled children only $[25,26]$. The mean age of adult patients ranged from 38 to 53 years $(n=128)$ and the mean age of children ranged from 0.9 to 18 years $(n=$ 66). The mean Acute Physiology and Chronic Health Evaluation scores were 25.2 (APACHE II) [23] and 54.9 (APACHE III) [24] in the two trials reporting baseline severity of illness. Details of the intervention varied considerably among the included trials (Table 1). The interventions ranged from a single plasma exchange treatment [24], to 34 to 36 hours of continuous plasma filtration [23,26], to daily plasma exchanges for 14 days [25]. Co-interventions were poorly reported, with two trials reporting the number of patients requiring ventilator and vasopressor support $[24,26]$.

\section{Primary outcomes and subgroup analyses}

Mortality either at 14 days [23], at 28 days [24,26], or at an undefined time interval [25] was reported in the included trials. We pooled data from all four trials $(n=$ 192) to generate a summary RR for mortality (Figure 2). Plasma exchange was not associated with a significant reduction in death from all causes $(\mathrm{RR}=0.83,95 \% \mathrm{CI}=$ 0.45 to 1.52$)$. The heterogeneity was moderate $\left(I^{2}=60 \%\right.$, uncertainly interval 0 to $87 \%$ ).

To investigate the statistical heterogeneity, we performed subgroup analyses according to the age of the study population. In the two trials enrolling adult patients, the RR of mortality associated with plasma exchange was 0.63 ( $95 \% \mathrm{CI}=0.42$ to $\left.0.96, I^{2}=0 \%, n=128\right)$. In the pediatric population, the RR for death associated 


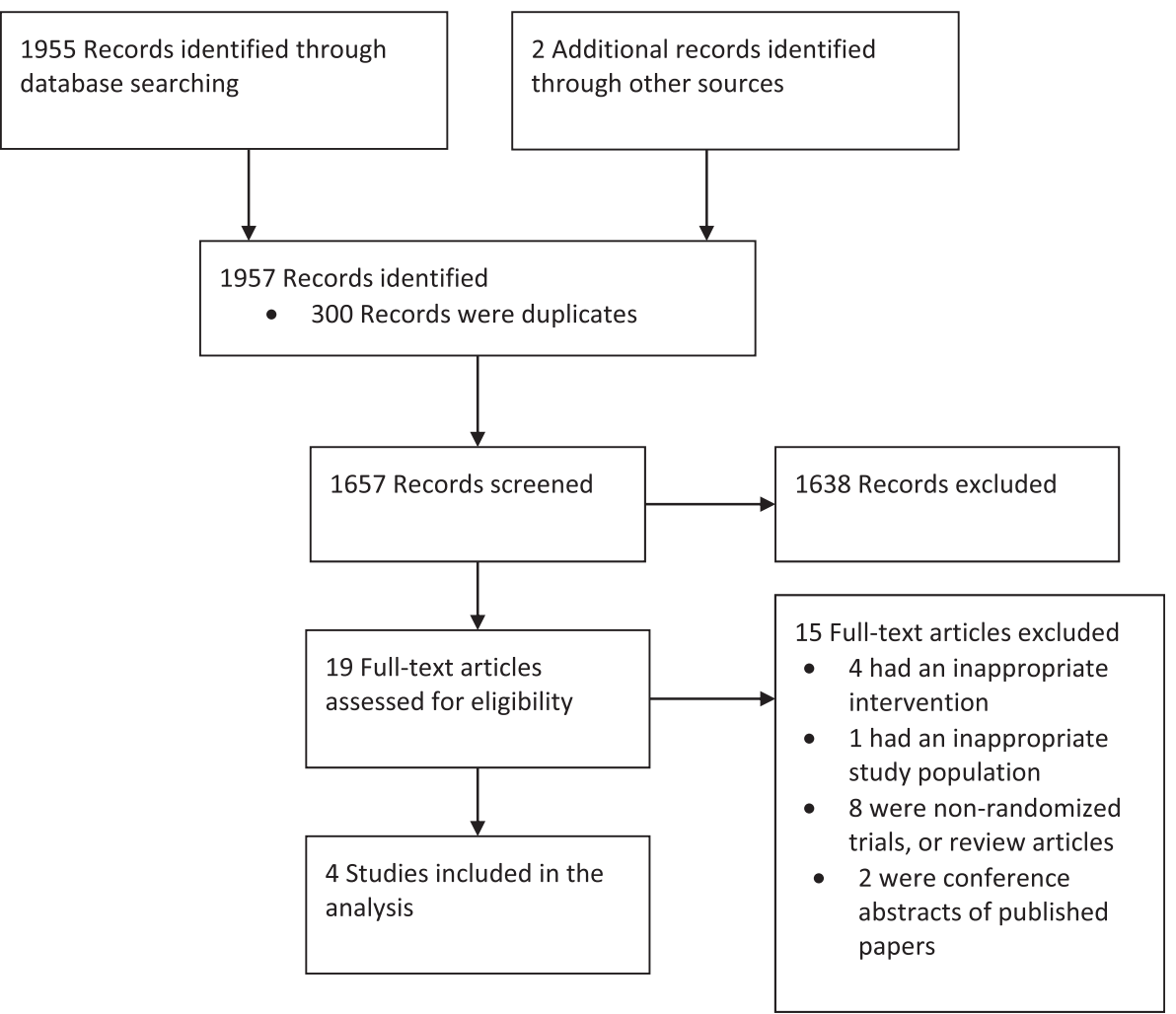

Figure 1 Preferred Reporting Items for Systematic Reviews and Meta-analysis study flow diagram.

with plasma exchange was $0.96(95 \% \mathrm{CI}=0.28$ to 3.38 , $I^{2}=60 \%, n=66$ ) (Figure 2). Subgroup analyses according to trial geography (for example, North American vs. other) resulted in nonsignificant and unstable point estimates (Additional file 4).

\section{Secondary outcomes}

None of the included trials reported data on ICU or hospital lengths of stay. Similarly, no trials included data on central venous catheter-related complications. Only one trial reported adverse events associated with apheresis [24]. In this trial, six episodes of transient hypotension and one allergic reaction to fresh frozen plasma were reported in 81 plasma exchange procedures.

\section{Discussion}

In this systematic review, we observed the overall RR for mortality in patients with sepsis treated with plasma exchange to be 0.83 ( $95 \% \mathrm{CI}=0.45$ to $\left.1.5, I^{2}=60 \%\right)$. In adults, plasma exchange was associated with a significant reduction in all-cause mortality. Hospital and ICU lengths of stay and adverse events were insufficiently reported. Clinical heterogeneity among included trials was moderate and all trials were at unclear or high risk of bias.

The pathogenesis of sepsis involves systemic inflammation and upregulation of coagulation $[27,28]$. This response is characterized by the production of excessive inflammatory cytokines (including tumor necrosis factor alpha, interleukin-6, and interleukin-1 $\beta$ ) [29], activation of coagulation and depletion of natural anticoagulants (antithrombin, tissue factor pathway inhibitor and protein C) [30,31]. Phase III trials examining replacement of deficient natural anticoagulants [32-35], and specific cytokines or circulating mediators [36-39] have shown inconsistent results. Therapies targeting broader aspects of immune homeostasis regulation of inflammation may be a more promising approach $[5,40]$. The role of plasma exchange has been well established in other conditions such as thrombotic thrombocytopenia purpura, a thrombotic microangiopathy associated with severely depleted levels of A Disintegrin-like and Metalloproteinase with Thrombospondin type-1 Motifs 13 (ADAMTS-13) [5,41]. Recently, ADAMTS-13 deficiency has been described in patients with severe sepsis and systemic inflammatory response syndrome, leading to an increased interest in the role of plasma exchange as an adjunct in the treatment of sepsis $[25,42]$. One included trial showed that ADAMTS-13 levels were significantly increased in patients randomized to receive plasma exchange [25]. Only one other trial provided data on inflammatory biomarkers, and this study showed significant decreases in plasma concentrations of C-reactive protein, alpha- 1 antitrypsin, haptoglobin, and 
Table 1 Baseline characteristics of included studies

\begin{tabular}{|c|c|c|c|c|c|c|c|}
\hline Study & $\begin{array}{l}N \\
\text { (P/Cntl) }\end{array}$ & Population & $\begin{array}{l}\text { Age } \\
\text { (P/Cntl) }\end{array}$ & $\begin{array}{l}\text { Illness severity } \\
\text { (P/Cntl) (mean) }\end{array}$ & Modality & Intensity & $\begin{array}{l}\text { Replacement } \\
\text { fluid }\end{array}$ \\
\hline \multirow{5}{*}{$\begin{array}{l}\text { Reeves } \\
\text { and } \\
\text { colleagues } \\
{[23]}\end{array}$} & \multirow[t]{5}{*}{$30(14 / 16)$} & Sepsis syndrome & \multirow{5}{*}{$\begin{array}{l}39 / 53 \\
\text { (mean) }\end{array}$} & \multirow{2}{*}{$\begin{array}{l}26.2 / 24.2 \\
\text { (adults) }\end{array}$} & \multirow{5}{*}{$\begin{array}{l}\text { Plasma filtration } \\
\text { (PF1000 plasma filter, } \\
\text { Gambro, Lund, Sweden) }\end{array}$} & \multirow{3}{*}{$\begin{array}{l}2 \text { PV during first } 4 \text { to } \\
6 \text { hours, } 3 \text { PV throughout } \\
\text { following } 28 \text { to } 30 \text { hours } \\
\text { (total five volumes) }\end{array}$} & \multirow{5}{*}{$\begin{array}{l}\text { FFP/protein } \\
\text { electrolyte } \\
\text { replacement } \\
\text { solution } \\
\text { (1:4 ratio) }\end{array}$} \\
\hline & & 22 adults & & & & & \\
\hline & & \multirow[t]{3}{*}{ Eight children } & & \multirow{3}{*}{$\begin{array}{l}\text { 26.3/26.9 } \\
\text { (children }^{\mathrm{a}} \text { ) } \\
\text { (APACHE II) }\end{array}$} & & & \\
\hline & & & & & & \multirow{2}{*}{$\begin{array}{l}213 \mathrm{ml} / \mathrm{kg} \text { (SD 42.2) } \\
\text { plasma exchanged }\end{array}$} & \\
\hline & & & & & & & \\
\hline \multirow{4}{*}{$\begin{array}{l}\text { Busund } \\
\text { and } \\
\text { colleagues } \\
{[24]}\end{array}$} & \multirow[t]{4}{*}{$106(54 / 52)$} & \multirow{4}{*}{$\begin{array}{l}\text { Adults with } \\
\text { severe sepsis } \\
\text { or septic shock }\end{array}$} & \multirow{4}{*}{$\begin{array}{l}41 / 48 \\
\text { (mean) }\end{array}$} & \multirow{4}{*}{$\begin{array}{l}56.4 / 53.5 \\
\text { (APACHE III) }\end{array}$} & \multirow{4}{*}{$\begin{array}{l}\text { Plasmapheresis } \\
\text { (PF-0.5 [Lvov, Russia] } \\
\text { and DK2-03 [Rjazan, Russia] } \\
\text { plasmapheresis machine) }\end{array}$} & \multirow{2}{*}{$\begin{array}{l}\text { One treatment of } 30 \text { to } \\
40 \mathrm{ml} / \mathrm{kg} \text { exchange }\end{array}$} & \multirow{4}{*}{$\begin{array}{l}\text { FFP:5\% albumin } \\
\text { replacement fluid } \\
\text { (1:1 ratio) }\end{array}$} \\
\hline & & & & & & & \\
\hline & & & & & & $\begin{array}{l}\text { (Repeated once if no } \\
\text { clinical improvement) }\end{array}$ & \\
\hline & & & & & & $\begin{array}{l}\text { Mean } 1,820 \pm 402 \mathrm{ml} \\
\text { (first session) and } \\
1,763 \pm 312 \mathrm{ml} \\
\text { (second session) }\end{array}$ & \\
\hline \multirow[t]{2}{*}{$\begin{array}{l}\text { Nguyen } \\
\text { and } \\
\text { colleagues } \\
{[25]}\end{array}$} & \multirow[t]{2}{*}{$10(5 / 5)$} & \multirow[t]{2}{*}{$\begin{array}{l}\text { Children with } \\
\text { thrombocytopenia } \\
\text { and multiorgan failure } \\
\text { due to sepsis }\end{array}$} & \multirow[t]{2}{*}{$\begin{array}{l}1 \text { to } 16 / 3 \\
\text { to } 18 \\
\text { (range) }\end{array}$} & \multirow[t]{2}{*}{$\begin{array}{l}25.7 / 25.7 \\
(\text { PELOD })^{a}\end{array}$} & \multirow[t]{2}{*}{$\begin{array}{l}\text { Plasma exchange } \\
\text { (SPECTRA, Gambro BCT, } \\
\text { Lakewood, Co, USA) }\end{array}$} & $\begin{array}{l}1.5 \text { volumes day } \\
1 ; 1.0 \text { volumes for } 14 \text { days) }\end{array}$ & \multirow[t]{2}{*}{$N R$} \\
\hline & & & & & & $\begin{array}{l}\text { Median of } 12 \\
\text { treatments given }\end{array}$ & \\
\hline \multirow{3}{*}{$\begin{array}{l}\text { Long and } \\
\text { colleagues } \\
{[26]}\end{array}$} & \multirow[t]{3}{*}{$48(25 / 23)$} & \multirow{3}{*}{$\begin{array}{l}\text { Children with } \\
\text { severe sepsis }\end{array}$} & \multirow{2}{*}{$\begin{array}{l}2.8(1.2 \\
\text { to } 9.6) \\
/ 2.8(0.9 \\
\text { to } 5)\end{array}$} & \multirow[t]{3}{*}{$N R$} & Plasma filtration & \multirow{3}{*}{$\begin{array}{l}2 \text { PV over first } 2 \text { hours } \\
(100 \mathrm{ml} / \mathrm{kg}) \text { followed } \\
\text { by } 6 \mathrm{PV} \text { over the next } \\
30 \text { hours }(300 \mathrm{ml} / \mathrm{kg})\end{array}$} & \multirow{3}{*}{$\begin{array}{l}\mathrm{FFP} / \text { protein } \\
\text { electrolyte } \\
\text { replacement } \\
\text { solution (1:4 ratio) }\end{array}$} \\
\hline & & & & & \multirow[t]{2}{*}{$\begin{array}{l}\text { (PF1000 or PF2000 } \\
\text { plasma filter, Gambro, } \\
\text { Lund, Sweden) }\end{array}$} & & \\
\hline & & & $\begin{array}{l}\text { Median } \\
\text { (IQR) }\end{array}$ & & & & \\
\hline
\end{tabular}

APACHE, Acute Physiology and Chronic Health Evaluation; Ctrl, control; FFP, fresh frozen plasma; IQR, interquartile range; NR, not reported; P, plasmapheresis;

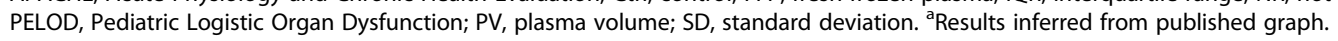

complement fraction $\mathrm{C} 3$ in patients who were randomized to plasma exchange [23].

Our meta-analysis builds upon a previously published review of blood purification modalities (including hemofiltration, hemoperfusion, plasma exchange or dialysis) in sepsis [43]. In that meta-analysis, authors restricted the analysis to adults and thus incorporated data from only two $[23,24]$ of the four trials on plasma exchange included in our review. The diversity of blood purification methods included in the previous review is an additional limitation. To increase the homogeneity of the study intervention and generalizability of the meta-analysis, we included only trials that studied plasma exchange as the intervention.

Our search identified an additional trial examining a proprietary method of blood purification called coupled plasma filtration absorption, which combines, in series, a plasma filter, a nonspecific absorption column, and a hemodialysis filter [44]. Plasma was not replaced. This trial found that coupled plasma filtration absorption did not reduce mortality in patients with septic shock but the authors hypothesized that there may be a mortality reduction when high volumes of plasma were processed. We excluded this trial from the formal meta-analysis because the coupled plasma filtration absorption process involves renal replacement therapy as part of the intervention, which was an a priori exclusion criteria for our review.

The strengths of our systematic review are the comprehensive search strategy, which included multiple electronic database searches, hand searching of grey literature and bibliographies of included trials and forward searching. We used an a priori published protocol and followed the recommended guidelines for conducting and reporting

Table 2 Risk of bias assessment of included studies

\begin{tabular}{|c|c|c|c|c|c|c|c|c|c|}
\hline Study & $\begin{array}{l}\text { Industry } \\
\text { funding }\end{array}$ & $\begin{array}{l}\text { Random } \\
\text { sequence } \\
\text { generation }\end{array}$ & $\begin{array}{l}\text { Allocation } \\
\text { concealment }\end{array}$ & $\begin{array}{l}\text { Blinding } \\
\text { (participants/ } \\
\text { personnel) }\end{array}$ & $\begin{array}{l}\text { Blinding } \\
\text { (outcome } \\
\text { assessors) }\end{array}$ & $\begin{array}{l}\text { Incomplete } \\
\text { outcome data }\end{array}$ & $\begin{array}{l}\text { Selective } \\
\text { reporting }\end{array}$ & $\begin{array}{l}\text { Other } \\
\text { bias }\end{array}$ & $\begin{array}{l}\text { Overall } \\
\text { assessment }\end{array}$ \\
\hline Reeves and colleagues [23] & No & Low & Low & Unclear & Unclear & Low & Low & $\mathrm{High}^{a}$ & High \\
\hline Busund and colleagues [24] & NR & Unclear & Unclear & Unclear & Unclear & Low & Low & $\operatorname{High}^{a}$ & High \\
\hline Nguyen and colleagues [25] & No & Unclear & Unclear & Unclear & Unclear & Low & Low & Unclear & Unclear \\
\hline Long and colleagues [26] & $N R$ & Unclear & Low & Unclear & Unclear & Low & Low & $\mathrm{High}^{\mathrm{a}}$ & High \\
\hline
\end{tabular}

NR, not reported. ${ }^{a}$ High risk due to significant baseline imbalances. 


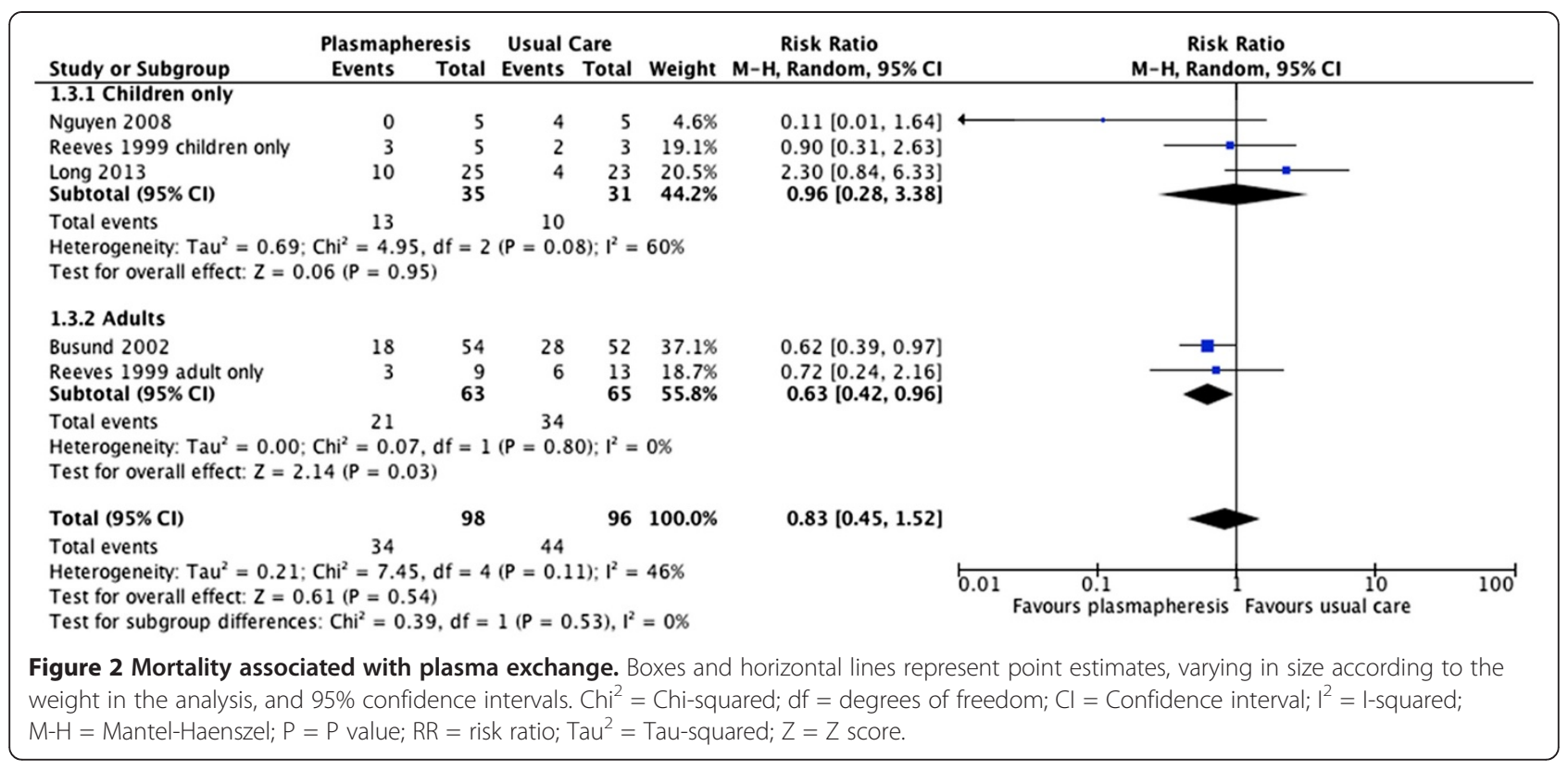

systematic reviews. We performed rigorous assessments of bias of our included trials, which facilitated data interpretation in the context of trial methodology. Finally, we explored potential sources of clinical and statistical heterogeneity with a priori defined subgroup analyses.

There are several limitations of this systematic review that relate to the primary data. First, the small number of trials and patients enrolled is an important limitation of the data. Second, there were substantial baseline imbalances to consider in several of the included trials. Baseline differences such as younger age [23] and fewer patients requiring mechanical ventilation [24] in the intervention group may have biased the results of those included trials in favor of plasma exchange. In addition, one trial had higher illness severity scores in the plasma exchange group, which would have biased the mortality estimate in favor of the null hypothesis [26]. Technical differences in the application of plasma exchange existed among the included trials. The optimal plasma separation method, dose, and type of replacement therapy remain uncertain. These procedural details must be considered when deciding upon specific apheresis interventions (for example, dose, frequency, replacement fluid, duration of study, and so forth) in future trials.

Although all trials reported objective patient-oriented outcomes such as mortality, the duration of follow-up in these trials is short (14 or 28 days) and represents a further limitation of these data because follow-up of 90 days may be required to capture the full impact of interventions on longer term vital status in patients with sepsis [45].

An additional notable limitation is that only one trial reported adverse effects related to plasma exchange [24].
No trials addressed central venous catheter-related complications. Although thought to be a safe procedure, plasma exchange can be associated with cardiovascular instability, allergic reaction, or infection and/or thrombosis related to the presence of a large-bore central venous catheter $[46,47]$.

\section{Conclusions}

Insufficient evidence exists to recommend plasma exchange as an adjunctive therapy for patients with sepsis or septic shock. Rigorous randomized controlled trials evaluating clinically relevant patient-centered outcomes are required to evaluate the impact of plasma exchange in this condition.

\section{Key messages}

- Sepsis and septic shock are leading causes of mortality in critically ill patients.

- Plasma exchange was not associated with a significant reduction in all-cause mortality overall, but was associated with a reduction in mortality in a subgroup of adult patients.

- Rigorous randomized controlled trials are required to evaluate the impact of plasma exchange in sepsis and septic shock.

\section{Additional files}

Additional file 1: Table S1. Presenting the research question using the PICOS structure. 
Additional file 2: Table S2. Presenting the study eligibility criteria. Additional file 3: Table S3. Presenting the PubMed/MEDLINE search strategy.

Additional file 4: Table S4. Presenting the mortality subgroup analyses.)

\section{Abbreviations}

ADAMTS-13: A Disintegrin-like and Metalloproteinase with Thrombospondin type-1 Motifs 13; Cl: confidence interval; RR: risk ratio.

\section{Competing interests}

The authors declare that they have no competing interests.

\section{Authors' contributions}

ER and RZ conceived and designed the study. ER, AMA-S, CF and RZ designed the search strategy. ER and BLH collected the data. ER, RZ and AMA-S performed statistical analyses. ER drafted the manuscript. AK, AFT, DJC, and DSH made substantial contributions to the design of the study. BLH, AK, AMA-S, JCM, CF, GR, AFT, DJC, DSH and RZ revised the manuscript critically for important intellectual content. All authors read and approved the final manuscript.

\section{Acknowledgements}

AFT receives salary support from the Fonds de la Recherche du Québec Santé. This entity had no role in the design or conduct of the study including but not limited to study identification, collection, management, analysis, and interpretation of the data, or preparation, review, or approval of the final report.

\section{Author details}

${ }^{1}$ Department of Internal Medicine, University of Manitoba, GC425-820 Sherbrook Street, HSC, Winnipeg R3A 1R9, Canada. 'Department of Haematology and Medical Oncology, CancerCare Manitoba, 675 McDermot Ave, Winnipeg R3E 0V9, Canada. ${ }^{3}$ Faculty of Medicine, University of Manitoba, 250 Brodie Centre, 727 McDermot Ave, Winnipeg R3E 3P5, Canada. ${ }^{4}$ George \& Fay Yee Center for Healthcare Innovation, University of Manitoba/Winnipeg Regional Health Authority, GE706-820 Sherbrook Street, HSC, Winnipeg R3A 1R9, Canada. ${ }^{5}$ Neil John Maclean Health Sciences Library, University of Manitoba, Brodie Centre, 727 McDermot Ave, Winnipeg R3E 3P5, Canada. 'Section of Critical Care Medicine, St. Michael's Hospital, 30 Bond Street, Toronto M5B 1W8, Canada. ${ }^{7}$ Ottawa Hospital, 501 Smyth Road, Ottawa K1H 8L6, Canada. ${ }^{8}$ Division of Critical Care Medicine, Department of Anesthesiology and Critical Care Medicine and Population Health and Optimal Health Practices Unit, CHU de Québec Research Center, Université Laval, 1401-18th Street, Québec G1J 1Z4, Canada. ${ }^{9}$ Department of Medicine, McMaster University, Hamilton L8S 4K1, Canada. ${ }^{10}$ Department of Clinical Epidemiology and Biostatistics, McMaster University, 1280 Main Street, West, Hamilton, Canada.

Received: 8 September 2014 Accepted: 27 November 2014 Published online: 20 December 2014

\section{References}

1. Angus DC, van der Poll T: Severe sepsis and septic shock. N Engl J Med 2013, 369:840-851.

2. Brun-Buisson C, Doyon F, Carlet J, Dellamonica P, Gouin F, Lepoutre A, Mercier JC, Offenstadt G, Regnier B: Incidence, risk factors, and outcome of severe sepsis and septic shock in adults: a multicenter prospective study in intensive care units. JAMA 1995, 274:968.

3. Schoenberg MH, Weiss M, Radermacher P: Outcome of patients with sepsis and septic shock after ICU treatment. Langenbecks Arch Surg 1998, 383:44-48.

4. Martin GS, Mannino DM, Eaton S, Moss M: The epidemiology of sepsis in the United States from 1979 through 2000. N Engl J Med 2003, 348:1546-1554.

5. Fortenberry JD, Paden ML: Extracorporeal therapies in the treatment of sepsis: experience and promise. Semin Pediatr Infect Dis 2006, 17:72-79.

6. Szczepiorkowski ZM, Winters $J$, Bandarenko N, Kim HC, Linenberger ML, Marques MB, Sarode R, Schwartz J, Weinstein R, Shaz BH: Apheresis Applications Committee of the American Society for A: Guidelines on the use of therapeutic apheresis in clinical practice - evidence-based approach from the Apheresis Applications Committee of the American Society for Apheresis. J Clin Apher 2010, 25:83-177.
7. Stegmayr B: Apheresis in patients with severe sepsis and multi organ dysfunction syndrome. Transfus Apher Sci 2008, 38:203-208.

8. Vain NE, Mazlumian JR, Swarner OW, Cha CC: Role of exchange transfusion in the treatment of severe septicemia. Pediatrics 1980, 66:693-697.

9. Bjorvatn B, Bjertnaes L, Fadnes HO, Flaegstad T, Gutteberg TJ, Kristiansen BE, Pape J, Rekvig OP, Osterud B, Aanderud L: Meningococcal septicaemia treated with combined plasmapheresis and leucapheresis or with blood exchange. Br Med J 1984, 288:439-441.

10. Brandtzaeg $P$, Sirnes $K$, Folsland B: Plasmapheresis in the treatment of severe meningococcal or pneumococcal septicaemia with DIC and fibrinolysis. Preliminary data on eight patients. Scand J Clin Lab Invest 1985, 45:53-55.

11. Drapkin MS, Wisch JS, Gelfand JA, Cannon JG, Dinarello CA: Plasmapheresis for fulminant meningococcemia. Pediatr Infect Dis J 1989, 8:399-400.

12. Scharfman WB, Tillotson JR, Taft EG, Wright E: Plasmapheresis for meningococcemia with disseminated intravascular coagulation. $N$ Engl J Med 1979, 300:1277-1278.

13. Schmidt J, Mann S, Mohr VD, Lampert R, Firla U, Zirngibl H: Plasmapheresis combined with continuous venovenous hemofiltration in surgical patients with sepsis. Intensive Care Med 2000, 26:532-537.

14. Van Deuren M, Santman FW, Van Dalen R, Sauerwein RW, Span LFR, Van der Meer JWM: Plasma and whole blood exchange in meningococcal sepsis. Clin Infect Dis 1992, 15:424-430.

15. Gardlund B, Sjolin J, Nilsson A, Roll M, Wickerts CJ, Wikstrom B, Wretlind B: Plasmapheresis in the treatment of primary septic shock in humans. Scand J Infect Dis 1993, 25:757-761.

16. Stegmayr BG: Plasma exchange in patients with septic shock including acute renal failure. Blood Purif 1996, 14:102-108.

17. Chandler J, Churchill R, Higgins J, Lasserson T, Tovey D: Methodological Expectations of Cochrane Intervention Reviews (MECIR) methodological standards for the conduct of new Cochrane Intervention Reviews, Version 2.1. The Cochrane Collaboration; 2011. [www.editorial-unit.cochrane.org/mecir]

18. Moher D, Liberati A, Tetzlaff J, Altman DG: Preferred reporting items for systematic reviews and meta-analyses: the PRISMA statement. BMJ 2009, 339:b2535.

19. Higgins JP, Green S (Eds): Cochrane Handbook for Systematic Reviews of Interventions, Version 5.1.0 edition. The Cochrance Collaboration; 2011. [www.cochrane-handbook.org]

20. Higgins JPT, Green S (Eds): Cochrane Handbook for Systematic Reviews of Interventions Version 5.0.1. The Cochrane Collaboration; 2008. [www.cochranehandbook.org]

21. Julian PTH, Douglas GA, Peter CG, Peter JÃ, David M, Andrew DO, Jelena S, Kenneth FS, Laura W, Jonathan ACS: The Cochrane Collaboration ${ }^{T M}$ tool for assessing risk of bias in randomised trials. BMJ 2011, 343:d5928.

22. Knaus WA, Draper EA: APACHE II: A severity of disease classification system. Crit Care Med 1985, 13:818-829.

23. Reeves JH, Butt WW, Shann F, Layton JE, Stewart A, Waring PM, Presneill JJ: Continuous plasmafiltration in sepsis syndrome. Plasmafiltration in Sepsis Study Group. Crit Care Med 1999, 27:2096-2104.

24. Busund R, Koukline V, Utrobin U, Nedashkovsky E: Plasmapheresis in severe sepsis and septic shock: a prospective, randomised, controlled trial. Intensive Care Med 2002, 28:1434-1439.

25. Nguyen TC, Han YY, Kiss JE, Hall MW, Hassett AC, Jaffe R, Orr RA, Janosky J, Carcillo JA: Intensive plasma exchange increases a disintegrin and metalloprotease with thrombospondin motifs-13 activity and reverses organ dysfunction in children with thrombocytopeniaassociated multiple organ failure. Crit Care Med 2008, 36:2878-2887

26. Long EJ, Shann F, Pearson G, Buckley D, Butt W: A randomised controlled trial of plasma filtration in severe paediatric sepsis. Crit Care Resusc 2013, 15:198-204.

27. Aird WC: The hematologic system as a marker of organ dysfunction in sepsis. Mayo Clin Proc 2003, 78:869-881.

28. Levy MM, Fink MP, Marshall JC, Abraham E, Angus D, Cook D, Cohen J, Opal SM, Vincent J-L, Ramsay G, SCCM/ESICM/ACCP/ATS/SIS: SCCM/ESICM/ACCP/ATS/SIS International Sepsis Definitions Conference. Crit Care Med 2003, 31:1250-1256.

29. Matthay MA: Severe sepsis - a new treatment with both anticoagulant and antiinflammatory properties. N Engl J Med 2001, 344:759-762.

30. Levi M, Schultz M, van der Poll T: Coagulation biomarkers in critically ill patients. Crit Care Clin 2011, 27:281-297.

31. Toltl LJ, Swystun LL, Pepler L, Liaw PC: Protective effects of activated protein C in sepsis. Thromb Haemost 2008, 100:582-592.

32. Afshari A, Wetterslev J, Brok J, Moller A: Antithrombin III in critically ill patients: systematic review with meta-analysis and trial sequential analysis. BMJ 2007, 335:1248-1251. 
33. Bernard GR, Vincent $J$, Laterre PF, LaRosa SP, Dhainaut JF, LopezRodriguez A, Steingrub JS, Garber GE, Helterbrand JD, Ely EW, Fisher CJ, Recombinant human protein C Worldwide Evaluation in Severe Sepsis (PROWESS) Study Group: Efficacy and safety of recombinant human activated protein C for severe sepsis. N Engl J Med 2001, 344:699-709.

34. Esmon CT: Introduction: are natural anticoagulants candidates for modulating the inflammatory response to endotoxin? Blood 2000, 95:1113-1116.

35. Abraham E, Reinhart K, Opal S, Demeyer I, Doig C, Rodriguez AL, Beale R, Svoboda P, Laterre PF, Simon S, Light B, Spapen H, Stone J, Seibert A, Peckelsen C, De Deyne C, Postier R, Pettila V, Artigas A, Percell SR, Shu V, Zwingelstein C, Tobias J, Poole L, Stolzenbach JC, Creasey AA, Optimus Trial Study Group: Efficacy and safety of tifacogin (recombinant tissue factor pathway inhibitor) in severe sepsis: a randomized controlled trial. JAMA 2003, 290:238-247.

36. Fisher CJ Jr, Dhainaut JF, Opal SM, Pribble JP, Balk RA, Slotman GJ, Iberti TJ, Rackow EC, Shapiro MJ, Greenman RL, Reines HD, Shelly MP, Thompson BW, LaBrecque JF, Catalano MA, Knaus WA, Sadoff JC, Phase III, rhlL-1 ra Sepsis Syndrome Study Group: Recombinant human interleukin 1 receptor antagonist in the treatment of patients with sepsis syndrome. Results from a randomized, double-blind, placebo-controlled trial. Phase III rhIL-1ra Sepsis Syndrome Study Group. JAMA 1994, 271:1836-1843.

37. Bone RC, Balk RA, Fein AM, Perl TM, Wenzel RP, Reines HD, Quenzer RW, Iberti TJ, Macintyre N, Schein RM: A second large controlled clinical study of E5, a monoclonal antibody to endotoxin: results of a prospective, multicenter, randomized, controlled trial. The E5 Sepsis Study Group. Crit Care Med 1995, 23:994-1006.

38. Cohen J, Carlet J: INTERSEPT: an international, multicenter, placebocontrolled trial of monoclonal antibody to human tumor necrosis factoralpha in patients with sepsis. International Sepsis Trial Study Group. Crit Care Med 1996, 24:1431-1440.

39. Abraham E, Wunderink R, Silverman H, Perl TM, Nasraway S, Levy H, Bone R, Wenzel RP, Balk R, Allred R, Pennington JE, Wherry JC, TNG-alpha MAb Sepsis Study Group: Efficacy and safety of monoclonal antibody to human tumor necrosis factor alpha in patients with sepsis syndrome. A randomized, controlled, double-blind, multicenter clinical trial. TNF-alpha MAb Sepsis Study Group. JAMA 1995, 273:934-941.

40. Ronco C, Tetta C, Mariano F, Wratten ML, Bonello M, Bordoni V, Cardona X, Inguaggiato P, Pilotto L, D'Intini V, Bellomo R: Interpreting the mechanisms of continuous renal replacement therapy in sepsis: the peak concentration hypothesis. Artif Organs 2003, 27:792-801.

41. Rock GA, Shumak KH, Buskard NA, Blanchette VS, Kelton JG, Nair RC, Spasoff RA: Comparison of plasma exchange with plasma infusion in the treatment of thrombotic thrombocytopenic purpura. Canadian Apheresis Study Group. N Engl J Med 1991, 325:393-397.

42. Cinel I, Opal SM: Molecular biology of inflammation and sepsis: a primer. Crit Care Med 2009, 37:291-304.

43. Zhou F, Peng Z, Murugan R, Kellum JA: Blood purification and mortality in sepsis: a meta-analysis of randomized trials. Crit Care Med 2013, 41:2209-2220.

44. Livigni S, Bertolini G, Rossi C, Ferrari F, Giardino M, Pozzato M, Remuzzi G,

GiViTI (Gruppo Italiano per la Valutazione degli Interventi in Terapia Intensiva): Efficacy of coupled plasma filtration adsorption (CPFA) in patients with septic shock: A multicenter randomised controlled clinical trial. BMJ Open 2014, 4:e003536.

45. Taori G, Ho KM, George C, Bellomo R, Webb SA, Hart GK, Bailey MJ: Landmark survival as an end-point for trials in critically ill patients comparison of alternative durations of follow-up: an exploratory analysis. Crit Care 2009, 13:R128.

46. McGee DC, Gould MK: Preventing complications of central venous catheterization. N Engl J Med 2003, 348:1123-1133.

47. Basic-Jukic N, Kes P, Glavas-Boras S, Brunetta B, Bubic-Filipi L, Puretic Z: Complications of therapeutic plasma exchange: experience with 4857 treatments. Ther Apher Dial 2005, 9:391-395.

\section{Submit your next manuscript to BioMed Central and take full advantage of:}

- Convenient online submission

- Thorough peer review

- No space constraints or color figure charges

- Immediate publication on acceptance

- Inclusion in PubMed, CAS, Scopus and Google Scholar

- Research which is freely available for redistribution

Submit your manuscript at www.biomedcentral.com/submit
C BiolMed Central 